\title{
Effects of Media and Plant Growth Regulators on Mini-Tuber Yield of Granola Cultivar of Potato in Aeroponics System
}

\author{
Sugiyono*, Lucky Prayoga, Elly Proklamasiningsih, Khavid Faozi dan Rendie Prasetyo \\ Department of Botany, Faculty of Biology, Universitas Jenderal Soedirman, Purwokerto, Indonesia
}

Diterima: 13 Juli 2021; Disetujui: 27 Juli 2021

\begin{abstract}
Potato is a perennial plant (Solanum tuberosum L.) in the nightshade family, which is one of the most developed and competitive vegetable crops compared to other vegetables. Furthermore, its production could not meet the increasing demand, which led to very intensive research and development programs. This research aims to examine the effect of nutrients and growth regulators on the yield of mini-tuber in the aeroponic system and to determine the best type of nutrient, as well as the type and concentration of plant growth regulators to increase mini-tubers yield in an aeroponics system. This experiment has been carried out experimentally using a split-split plot design. The main plots were the types of nutrient media, which consisted of Grow More-modified nutrient and AB-Mix nutrient. The sub-plots were the types of plant growth regulator (PGR), which consisted of BAP and $\mathrm{GA}_{3}$, while the sub-sub-plot were the concentrations of PGR, which consisted of $0 ; 5 ; 10 ; 15 ; 20$ and $25 \mu \mathrm{M}$. Each combination of treatments was repeated three times. The results showed that the use of media type, PGR and PGR concentration affected the formation and yield of Granola cultivar of potato mini-tubers. Knols grown in $\mathrm{AB}$-Mix nutrient medium supplemented with $20 \mu \mathrm{M} \mathrm{GA}_{3}$ resulted in the best mini-tuber formation, as shown by the average number of mini-tubers of 8.33, the total weight of mini-tubers of $21.38 \mathrm{~g}$ and the average mini-tuber diameter of $13.05 \mathrm{~mm}$.
\end{abstract}

Keywords: AB-mix; BAP; $\mathrm{GA}_{3}$; grow more; precision agriculture

\section{Pengaruh Jenis Media dan Zat Pengatur Tumbuh Tumbuhan pada Hasil Umbi Mini Kentang Kultivar Granola Secara Aeroponik}

\begin{abstract}
Abstrak
Kentang merupakan salah satu tanaman sayuran yang paling berkembang karena memiliki daya saing tinggi dibandingkan sayuran lain. Kentang merupakan salah satu komoditas yang mendapat prioritas dalam program penelitian dan pengembangan. Penelitian ini bertujuan untuk mempelajari pengaruh nutrisi dan zat pengatur tumbuh terhadap hasil umbi mini kentang kultivar Granola. Penelitian ini merupakan penelitian eksperimental dengan Rancangan Petak-petak Terpisah dengan tiga ulangan. Petak utama adalah jenis nutrien yang terdiri dari nutrien Grow More-dimodifikasi dan AB-Mix. Anak petak adalah jenis zat pengatur tumbuh (ZPT) yang terdiri dari BAP dan $G A_{3}$, sedangkan anak-anak petak adalah konsentrasi ZPT yang terdiri dari 0, 5, 10, 15, 20, dan $25 \mu M$. Penelitian ini menunjukkan bahwa penggunaan jenis media tanam, serta jenis dan konsentrasi ZPT yang digunakan dapat mempengaruhi pembentukan serta produksi umbi mini ketang kultivar Granola. Knol yang
\end{abstract}

\footnotetext{
*Corresponding author: gieks_sugiyono@hotmail.com

Cite this as: Sugiyono, Prayoga, L., Proklamasiningsih, E., Faozi, K., \& Prasetyo, R. (2021). Effects of Media and Plant Growth Regulators on Mini-Tuber Yield of Granola Cultivar of Potato in Aeroponics System. AgriHealth: Journal of Agri-food, Nutrition and Public Health, 2(1), 55-64. doi: http://dx.doi.org/10.20961/ agrihealth.v2i1.53197
} 
ditumbuhkan pada media AB-Mix dengan penambahan $20 \mu M G_{3}$ menghasilkan umbi mini kentang Granola terbaik, sebagaimana ditunjukkan dengan rataan jumlah umbi mini sebesar 8,33 umbi, berat total umbi mini sebesar 21,38 g dan rataan diameter mencapai 13,05 $\mathrm{mm}$.

Kata kunci: AB-mix; BAP; GA, grow more; pertanian presisi

\section{INTRODUCTION}

Potato (Solanum tuberosum L.) is one of the most developed vegetable crops due to its high competitiveness compared to others (Hidayat, 2016). Furthermore, it is an essential food commodity in Indonesia that is needed throughout the year. The high demand results in the need for the production of larger quantities and highquality potatoes. Subsequently, the production of potatoes in Indonesia has increased from $1,219,270$ tons in 2015 to $1,314,657$ tons in 2019 (Statistics Indonesia, 2020). However, this production could not meet the constantly increasing market demand for potatoes. The Granola cultivar of potato is one of the most cultivated cultivars in Indonesia, which has high productivity and long harvest time. Research and development programs have been prioritized to increase potato production in Indonesia (Karjadi, 2014).

Potato production in developing countries is hampered by constraints such as poor soil fertility, pest and diseases, as well as an inadequate supply of high-quality tuber seeds. The majority of farmers either recycle their own seeds or get them from informal sources, which leads to a degeneration of the seed and the accumulation of tuber-borne diseases and therefore lowers the yields (Muthoni et al., 2013). A good tuber is one of the most important factors in increasing potato productivity (Wulandari et al., 2014; Nuraini et al., 2016). In order to alleviate the problem of the lack of good quality seeds, strategies for rapid propagation have been carried out, such as tissue culture in conjunction with hydroponics and aeroponics (Muthoni et al., 2013). The use of an aeroponics system for minituber production offers several benefits which include: 1) optimization of root aeration, resulting in better yield compared to classic hydroponics system; 2) regardless of the season, the plants can be grown all year round, resulting in higher yields; 3) intensive production can be performed in a limited area, which has resulted in gaining more yield and more effective; 4) no loss of fertility, therefore no plant rotation is needed; 5) tuber can be harvested safely at any time and in any size, which enables the control of the mini-tuber size (Otazu, 2010; Mbiyu et al., 2012). Sumarni et al. (2013) also added that the use of aeroponic techniques on potato tuber seed production can improve the quality of tuber seed produced.

Aeroponics is a cultivation system that can increase the quality and yield of the product and is very efficient in the use of soil, water and nutrients, therefore it is incorporated into precision agriculture. Precision agriculture can be interpreted as a precise and accurate agricultural model, which includes the application of nutrients, pesticides, water sources, planning and control that are carried out precisely and accurately (Cambouris et al., 2014; Schimmelpfennig, 2016; Neforawati et al., 2019; Shafi et al., 2019). Compared to conventional techniques, the aeroponic systems can initiate potato tubers faster (Dianawati et al., 2013). The production of potatoes in an aeroponic system is influenced by several factors, including potato genotype, Plant Growth Regulator (PGR), light, temperature, humidity, media and planting techniques (Sonnewald and Sonnewald, 2014; Fadhil et al., 2015). The application of PGR in aeroponic systems can induce the formation of stolons that later develop into tubers.

The types of PGR that can be used to stimulate plant growth and productivity including 6-Benzylaminopurine (BAP), which stimulates shoot growth (Feng et al., 2012; Munarti and Kurniasih, 2014) and Gibberellic acid $\left(\mathrm{GA}_{3}\right)$ that stimulates stems and leaf area growth (Karjadi, 2014). The growth of axillary shoots is the beginning of the formation of the mini-tuber. These shoots can develop into stolons and mini-tubers if the conditions are suitable for the formation of tuber (Chiipanthenga et al., 2012; Pratama et al., 2014). The $\mathrm{GA}_{3}$ can induce mini-tuber formation because it stimulates the differentiation and morphogenesis, especially the formation of shoots, which is very important in the formation of mini-tuber (Karjadi and Waluyo, 2017). This research aims to examine 
the effect of nutrients and growth regulators on the production of mini-tubers in the aeroponic system and to determine the best type of nutrient as well as the type and concentration of plant growth regulators to increase the yield of mini-tuber in the aeroponics system.

\section{MATERIALS AND METHODS}

This research has been conducted at the Kledung Horticultural Seed Garden, Temanggung Regency, Central Java Province of Indonesia. Furthermore, it was carried out experimentally using a split-split plot design. The main plots were the types of nutrient media consisting of Grow More-modified nutrient and AB-Mix nutrient. The sub-plot was the types of PGR which consisted of BAP and $\mathrm{GA}_{3}$, while the sub-sub-plot was the concentration of PGR, which consisted of $0,5,10,15,20$ and $25 \mu \mathrm{M}$. Each treatment combination was replicated three times.

\section{Aeroponics system}

The aeroponics system, which includes cubical size, plant material (A certified-G1-tuber-seedderived plantlets (knol) of Granola cultivar), planting techniques, planting density (75 plants $\mathrm{m}^{-2}$ ) and plant maintenance were carried out according to procedures described by Sugiyono et al. (2021). The knol and planting density of 75 plants $\mathrm{m}^{-2}$ were used in this research because they showed the best results in the previous study (Sugiyono et al., 2021).

\section{Data collection and analysis}

The variable observed was the yield of Granola cultivar potato mini-tuber. The parameters measured include the total number of mini-tubers, mini-tuber total weight, average weight per minituber and mini-tuber average diameter. The data were collected and subsequently analyzed using an analysis of variance (ANOVA), followed by the Honestly Significance Difference (HSD) Test, with a confidence level of $95 \%$ when a significant difference between treatments was observed.

\section{RESULTS AND DISCUSSION}

The development of potato tuber consists of two aspects: morphological development and biochemical changes that lead to the formation and storage of carbohydrates. During morphological development, the formation of the tuber consists of two sequential processes, namely the formation of the stolon and the formation of the tuber at its tip. The lateral shoot can result in a stolon due to the changes in cell division and cell elongation. It is generally accepted that the longitudinal growth of the stolon stopped shortly before the swelling of the stolon tip. The cells inside the pit and the cortex enlarge and begin to divide lengthwise, resulting in the swelling of the stolon tip. Then the random cell division and enlargement occur mainly in the perimedular zone until the specified tuber size is reached (Momena et al., 2014; Tierno et al., 2014; Rykaczewska, 2016).

The results of the HSD test on the effect of nutrients on mini-tuber formation showed that only the total weight of the mini-tubers is controlled by the nutrients used. Table 1 shows that $\mathrm{AB}$-mix resulted in a significantly heavier average mini-tubers total weight. According to Tiwari et al. (2020), the use of media with low $\mathrm{N}$ concentrations can accelerate mini-tuber induction. An nitrogen deficiency in the media has a role in shortening the vegetative phase and accelerating the generative phase in such a way that the formation of mini-tubers will be formed more quickly (Buckseth et al., 2016). AB-Mix is a commercially available hydroponics solution that is rich in both macronutrients, especially potassium $(40 \%)$, phosphorus (23\%), nitrogen (14\%) and micronutrients. Plant growth on the AB-mix medium can be seen in Figure 1. In contrast, Grow More is a commercially available leaf-manure that contains slightly lower macro and micronutrient content. It seems that the AB-Mix nutrient is sufficient to support the growth and the formation of mini-tubers of Granola cultivar of potato, due to its higher nutrients content compare to that of Grow More medium. This finding was consistent with the finding previously reported by Sugiyono et al. (2021).

Further HSD analysis (Table 2) showed that the interaction between nutrients and PGRs controlled the average mini-tuber weight of Granola cultivar of potato in the aeroponics system. It was also discovered that the knol planted on AB-Mix nutrient treated with $\mathrm{GA}_{3}$ produced a significantly heavier average of minituber weight. The $\mathrm{GA}_{3}$ application aims to improve internode elongation and stimulate tuber enlargement due to the longitudinal growth of the stolon. The $\mathrm{GA}_{3}$ can accelerate the formation of stolons which later develop into shoots or tubers (Salem and Hassanein, 2017). 
Table 1. The effect of different nutrients on total-mini tuber weight of Granola cultivar of potato in aeroponics system

\begin{tabular}{lc}
\hline \multicolumn{1}{c}{ Nutrient } & Total mini-tuber weight \\
\hline Grow More-modified Nutrient & $5.56^{\mathrm{b}}$ \\
AB-mix & $8.41^{\mathrm{a}}$ \\
\hline
\end{tabular}

Note: Numbers followed by different letters show significantly different in HSD $(\leq 0.05)$

Table 2. The effect of interaction between nutrients and PGRs on the average mini-tuber weight of Granola cultivar of potato in aeroponics system

\begin{tabular}{ccc}
\hline Type of nutrient & PGR type & Average mini-tuber weight \\
\hline Grow More-modified Nutrient & $\mathrm{BAP}$ & $1.67^{\mathrm{ab}}$ \\
& $\mathrm{GA}_{3}$ & $1.32^{\mathrm{b}}$ \\
\hline AB-mix nutrient & $\mathrm{BAP}^{\mathrm{b}}$ & $1.39^{\mathrm{b}}$ \\
& $\mathrm{GA}_{3}$ & $2.29^{\mathrm{a}}$ \\
\hline
\end{tabular}

Note: Numbers followed by different letters show significantly different in HSD $(\leq 0.05)$



a.

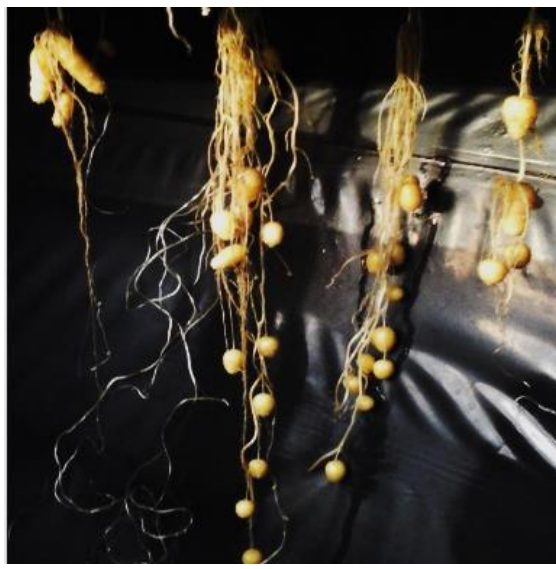

b.

Figure 1. The appearance of potato cultivar Granola in an aeroponics system, a) the condition of the potato cultivar Granola crop in an aeroponic system, b) mini-tubers generated in an aeroponic system

Furthermore, the results of the HSD test on the effect of PGR concentration on the mini-tuber formation of Granola cultivar of potato in aeroponics system (Table 3) showed that PGR at a concentration of $0 \mu \mathrm{M}$ produced the highest average number of tuber ( 8.58 tubers plant $\left.{ }^{-1}\right)$ and the highest average tuber weight $\left(9.85 \mathrm{~g} \mathrm{plant}^{-1}\right)$ or 514.8 tubers $\mathrm{m}^{-2}$. These results also indicated that the knols planted on the media without growth regulator produced the highest number of tubers, which led to the heaviest total tuber weight. This also indicated that Grow More-modified nutrient and AB-Mix medium are capable of inducing stolon formation and growth and therefore accelerating the induction of the mini-tubers.

Table 3. The effect of different concentrations of PGR on the total number and total weight of minitubers of Granola cultivar of potato in aeroponics system

\begin{tabular}{ccc}
\hline The concentration of PGR $(\mu \mathrm{M})$ & Number of mini-tuber & Total mini-tuber weight \\
\hline 0 & $8.58^{\mathrm{a}}$ & $9.85^{\mathrm{a}}$ \\
5 & $3.42^{\mathrm{b}}$ & $6.54^{\mathrm{bc}}$ \\
10 & $5.17^{\mathrm{b}}$ & $5.90^{\mathrm{bc}}$ \\
15 & $4.75^{\mathrm{b}}$ & $5.88^{\mathrm{bc}}$ \\
20 & $4.67^{\mathrm{b}}$ & $8.85^{\mathrm{b}}$ \\
25 & $3.50^{\mathrm{b}}$ & $4.90^{\mathrm{c}}$ \\
\hline
\end{tabular}

Note: Numbers followed by different letters show significantly different in HSD $(\leq 0.05)$ 
Looking at the influence of the interaction between nutrient type and PGR concentration mini-tubers average diameter, the results of the HSD test (Table 4) showed that ABmix nutrients without the addition of PGR resulted in the largest average tuber diameter (12.19 mm). AB-mix media is a hydroponic solution with high macronutrients, especially potassium, phosphorus, nitrogen and micronutrients. This high nutrient content could have been sufficient to stimulate the production of mini-tubers. Sugiyono et al. (2021) reported that the use of AB-Mix medium was very effective for the formation of mini-tubers as indicated in the number of average weight and diameter.

Table 4. The effect of interaction between nutrients and concentrations of PGR on the average minituber diameter of Granola cultivar of potato in an aeroponics system

\begin{tabular}{ccc}
\hline Type of nutrient & The concentration of PGR $(\mu \mathrm{M})$ & Average mini-tuber diameter \\
\hline Grow More-modified nutrient & 0 & $8.76^{\mathrm{e}}$ \\
5 & $10.98^{\mathrm{abcd}}$ \\
10 & $9.42^{\mathrm{de}}$ \\
15 & $9.71^{\mathrm{cde}}$ \\
20 & $10.85^{\mathrm{abcde}}$ \\
25 & $11.70^{\mathrm{abc}}$ \\
\hline AB-mix nutrient & 0 & $12.19^{\mathrm{a}}$ \\
& 5 & $11.90^{\mathrm{ab}}$ \\
10 & $11.07^{\mathrm{abcd}}$ \\
15 & $10.25^{\mathrm{abcde}}$ \\
20 & $11.36^{\mathrm{abcd}}$ \\
25 & $9.97^{\mathrm{bcde}}$ \\
\hline
\end{tabular}

Note: Numbers followed by different letters show significantly different in HSD $(\leq 0.05)$

In addition, the results of the HSD test on the effect of the interaction between PGR type and concentration on total mini-tubers weight (Table 5) showed that the use of $\mathrm{GA}_{3}$ at a concentration of $20 \mu \mathrm{M}$ resulted in the heaviest mini-tuber $(12.91 \mathrm{~g})$. This finding indicated that $\mathrm{GA}_{3}$ at a concentration of $20 \mu \mathrm{M}$ can increase both the source strength and sink capacity in the formation of potato mini-tubers. Gibberellin increases cellular proliferation, which improves the development of the lateral organs and mini-tubers growth (Kumlay, 2014; Sonnewald and Sonnewald, 2014; Wang et al., 2018).

Table 5. The effect of interaction between PGRs and concentrations on the total mini-tuber weight of Granola cultivar of potato in an aeroponics system

\begin{tabular}{ccc}
\hline Type of PGR & The concentration of PGR $(\mu \mathrm{M})$ & Total mini-tuber weight \\
\hline BAP & $0 \mu \mathrm{M}$ & $9.25^{\text {abc }}$ \\
& $5 \mu \mathrm{M}$ & $5.52^{\mathrm{c}}$ \\
$10 \mu \mathrm{M}$ & $6.02^{\mathrm{bc}}$ \\
$15 \mu \mathrm{M}$ & $6.94^{\mathrm{bc}}$ \\
$20 \mu \mathrm{M}$ & $4.80^{\mathrm{c}}$ \\
$25 \mu \mathrm{M}$ & $5.18^{\mathrm{c}}$ \\
\hline $\mathrm{GA}_{3}$ & $0 \mu \mathrm{M}$ & $10.46^{\mathrm{ab}}$ \\
& $5 \mu \mathrm{M}$ & $7.57^{\mathrm{bc}}$ \\
& $10 \mu \mathrm{M}$ & $5.77^{\mathrm{bc}}$ \\
& $15 \mu \mathrm{M}$ & $4.81^{\mathrm{c}}$ \\
$20 \mu \mathrm{M}$ & $12.91^{\mathrm{a}}$ \\
$25 \mu \mathrm{M}$ & $4.61^{\mathrm{c}}$ \\
\hline
\end{tabular}

Note: Numbers followed by different letters show significantly different in HSD $(\leq 0.05)$ 
The results of the HSD test on the effect of the interaction between the type of nutrients, type of PGRs and PGR concentration on the formation of mini-tubers of Granola cultivar of potato in aeroponics system (Table 6) showed that the knols grown in Grow More-modified nutrient medium at $0 \mu \mathrm{M} \mathrm{GA}_{3}$ resulted in the highest total number of mini-tubers (Figure 2), although it was not significantly different with that of the knol grown in $\mathrm{AB}-$ Mix medium supplemented with $20 \mu \mathrm{M}$ $\mathrm{GA}_{3}$. Gibberellin was reported to be more effective in inducing the growth of potato shoots than its ability to induce tuber formation. Other PGRs, such as auxin, are believed to be more effective in inducing the formation of potato tuber (Faramarzi et al., 2012; Roumeliotis et al., 2012). Table 6 also showed that the knols grown in AB-Mix nutrient medium supplemented with $\mathrm{GA}_{3}$ $20 \mu \mathrm{M}$ resulted in the highest total mini-tuber weight $\left(21.38 \mathrm{~g} \mathrm{plant}^{-1}\right)$. These results showed that $\mathrm{AB}-\mathrm{Mix}$ and $\mathrm{GA}_{3}$ nutrients at a concentration of $20 \mu \mathrm{M}$ can produce the highest source strength and sink capacity to form potato mini-tubers in aeroponic systems.

Table 6. Effect of interactions among nutrients, PGRs and concentrations on mini-tuber formation of Granola cultivar of potato in an aeroponics system

\begin{tabular}{|c|c|c|c|c|c|}
\hline $\begin{array}{c}\text { The type of } \\
\text { nutrient }\end{array}$ & $\begin{array}{l}\text { Type of } \\
\text { PGR }\end{array}$ & $\begin{array}{c}\text { The concentration } \\
\text { of PGR }(\mu \mathrm{M})\end{array}$ & $\begin{array}{l}\text { Total number } \\
\text { of mini-tuber }\end{array}$ & $\begin{array}{l}\text { Total mini- } \\
\text { tuber weight }\end{array}$ & $\begin{array}{l}\text { Average mini- } \\
\text { tuber diameter }\end{array}$ \\
\hline \multirow{12}{*}{$\begin{array}{l}\text { Grow More- } \\
\text { modified } \\
\text { nutrient }\end{array}$} & \multirow[t]{6}{*}{ BAP } & 0 & $5.67^{\mathrm{bcd}}$ & $6.00^{\text {bcd }}$ & $9.56^{\text {cdef }}$ \\
\hline & & 5 & $4.67^{\mathrm{bcd}}$ & $5.94^{\text {bcd }}$ & $10.38^{\text {bdef }}$ \\
\hline & & 10 & $9.33^{\mathrm{ab}}$ & $4.76^{\mathrm{d}}$ & $7.51^{\mathrm{f}}$ \\
\hline & & 15 & $5.00^{\mathrm{bcd}}$ & $7.88^{\mathrm{bcd}}$ & $10.42^{\text {bcdef }}$ \\
\hline & & 20 & $3.33^{\mathrm{cd}}$ & $5.71^{\mathrm{bcd}}$ & $10.97^{\text {abcde }}$ \\
\hline & & 25 & $2.67^{\mathrm{d}}$ & $7.16^{\mathrm{bcd}}$ & $13.83^{\mathrm{a}}$ \\
\hline & \multirow[t]{6}{*}{$\mathrm{GA}_{3}$} & 0 & $12.67^{\mathrm{a}}$ & $8.31^{\mathrm{bcd}}$ & $7.96^{\mathrm{ef}}$ \\
\hline & & 5 & $2.67^{\mathrm{d}}$ & $5.37^{\mathrm{cd}}$ & $11.58^{\mathrm{abcd}}$ \\
\hline & & 10 & $2.33^{\mathrm{d}}$ & $4.00^{\mathrm{d}}$ & $11.33^{\mathrm{abcd}}$ \\
\hline & & 15 & $4.33^{\mathrm{bcd}}$ & $3.62^{\mathrm{d}}$ & $9.00^{\mathrm{def}}$ \\
\hline & & 20 & $3.00^{\mathrm{d}}$ & $4.44^{\mathrm{d}}$ & $10.72^{\text {bcde }}$ \\
\hline & & 25 & $4.67^{\mathrm{bcd}}$ & $3.55^{\mathrm{d}}$ & $9.57^{\text {cdef }}$ \\
\hline \multirow{12}{*}{$\begin{array}{l}\text { AB-mix } \\
\text { nutrient }\end{array}$} & \multirow[t]{6}{*}{ BAP } & 0 & $9.33^{\mathrm{ab}}$ & $12.50^{\mathrm{bc}}$ & $12.26^{\mathrm{abc}}$ \\
\hline & & 5 & $3.33^{\mathrm{cd}}$ & $5.10^{\mathrm{d}}$ & $11.80^{\mathrm{abcd}}$ \\
\hline & & 10 & $4.33^{\mathrm{bcd}}$ & $7.28^{\mathrm{bcd}}$ & $11.27^{\mathrm{abcd}}$ \\
\hline & & 15 & $6.00^{\mathrm{bcd}}$ & $6.00^{\mathrm{bcd}}$ & $9.94^{\text {bcdef }}$ \\
\hline & & 20 & $4.00^{\mathrm{cd}}$ & $3.89^{\mathrm{d}}$ & $9.68^{\text {cdef }}$ \\
\hline & & 25 & $2.67^{\mathrm{d}}$ & $3.20^{\mathrm{d}}$ & $9.22^{\text {cdef }}$ \\
\hline & \multirow[t]{6}{*}{$\mathrm{GA}_{3}$} & 0 & $6.67^{\text {bcd }}$ & $12.61^{\mathrm{b}}$ & $12.11^{\mathrm{abcd}}$ \\
\hline & & 5 & $3.00^{\mathrm{d}}$ & $9.76^{\mathrm{bcd}}$ & $12.00^{\mathrm{abcd}}$ \\
\hline & & 10 & $4.67^{\mathrm{bcd}}$ & $7.55^{\mathrm{bcd}}$ & $10.88^{\text {abcde }}$ \\
\hline & & 15 & $3.67^{\mathrm{cd}}$ & $6.00^{\mathrm{bcd}}$ & $10.56^{\text {bcdef }}$ \\
\hline & & 20 & $8.33^{\mathrm{abc}}$ & $21.38^{\mathrm{a}}$ & $13.05^{\mathrm{ab}}$ \\
\hline & & 25 & $4.00^{\mathrm{cd}}$ & $5.67^{\mathrm{bcd}}$ & $10.73^{\text {bcde }}$ \\
\hline
\end{tabular}

Note: Numbers followed by different letters show significantly different in HSD $(\leq 0.05)$

Table 6 also showed that the knols grown in Grow More-modified nutrient medium supplemented with $25 \mu \mathrm{M}$ BAP resulted in the largest average mini-tuber diameter (13.83 $\mathrm{mm}$ mini-tuber ${ }^{-1}$ ) and was not significantly different from that of the knol grown in $\mathrm{AB}$ Mix medium supplemented with $20 \mu \mathrm{M} \mathrm{GA}_{3}$. These results indicated that the Grow Moremodified nutrient supplemented with $25 \mu \mathrm{M}$
BAP can produce the highest source strength that would convert sufficient photosynthate to be translocated into mini-tubers and therefore having the largest diameter of the mini-tubers. Aksenova et al. (2012) showed that the inflows of cytokinin from the roots situated close to the stolons regulate the sinking ability of the tubers. Examining the number of mini-tubers formed, total weight and diameter, it can be seen that 
the knols has grown in AB-Mix medium supplemented with $20 \mu \mathrm{M}$ GA3 resulted in the best formation of the mini-tuber. This treatment

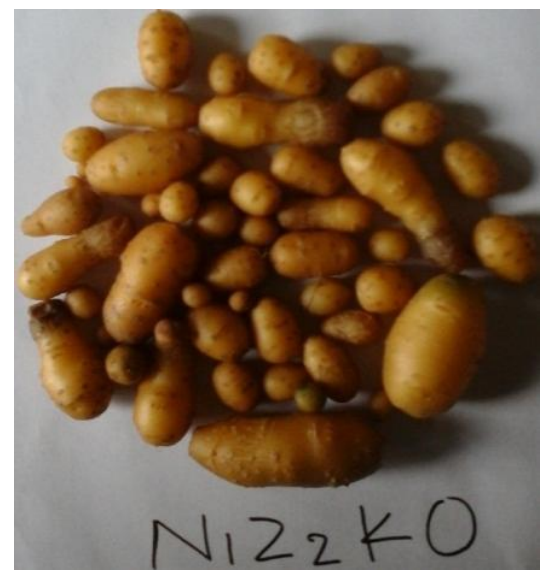

a. yielded up to 8.33 tubers plant ${ }^{-1}$ with the total mini-tuber weight of $21.38 \mathrm{~g} \mathrm{plant}^{-1}$ and an average diameter of $13.05 \mathrm{~mm}_{\text {mini-tuber }}{ }^{-1}$.



b.

Figure 2. The appearance of Granola cultivar potato tubers in an aeroponic system: a) Treatment of Grow More media with $\mathrm{GA}_{3} 0 \mu \mathrm{M} . \mathrm{b}$ ) treatment of Grow More media with $\mathrm{GA}_{3} 10 \mu \mathrm{M}$

Due to modifications in cell division and extension, the lateral buds grow to form stolons. Cells in the pit and cortex expand and divide the extension lengthwise in the direction of the development of the tuber, therefore producing an end swelling of the stolon. The tuber morphology obtained appeared to be oval and not round. This indicates a longer longitudinal growth, although the tubers have formed. However. the addition of BAP or $\mathrm{GA}_{3}$ treatment seems to cause this longitudinal growth to continue at a faster rate than the growth rate of tuber enlargement, resulting in an oblong tuber morphology (Aksenova et al., 2012; Kianmehr et al., 2012; Roumeliotis et al., 2012).

\section{CONCLUSION}

This research showed that the use of the media type, the concentration of PGRs and PGR affects the formation and yield of Granola potato cultivar mini-tubers. The knols has grown in AB-Mix medium supplemented with $20 \mu \mathrm{M} \mathrm{GA}_{3}$ resulted in the best mini-tubers formation, as shown on the average number of mini-tubers of 8.33 , the total weight of minitubers of $21.38 \mathrm{~g}$ and the average mini-tuber diameter of $13.05 \mathrm{~mm}$.

\section{ACKNOWLEDGEMENT}

The authors express their profound gratitude to the Rector of Jenderal Soedirman University and the Ministry of Research, Technology and
Higher Education for the funding of this research through the National Strategic Research Grant (Grant Number 2046).

\section{REFERENCES}

Aksenova, N. P., Konstantinova, T. N., Golyanovskaya, S. A., Sergeeva, L. I., \& Romanov, G. A. (2012). Hormonal regulation of tuber formation in potato plants. Russian Journal of Plant Physiology, 59(4), 451466. https://doi.org/10.1134/S1021443712040 024

Buckseth, T., Sharma, A. K., Pandey, K. K., Singh, B. P., \& Muthuraj, R. (2016). Methods of pre-basic seed potato production with special reference to aeroponics-A review. Scientia Horticulturae, 204, 79-87. https:// doi.org/10.1016/j.scienta.2016.03.041

Cambouris, A. N., Zebarth, B. J., Ziadi, N., \& Perron, I. (2014). Precision agriculture in potato production. Potato Research, 57(3-4), 249-262. https://doi.org/10.1007/s11540-0149266-0

Chiipanthenga, M., Maliro, M., Demo, P., \& Njoloma, J. (2012). Potential of aeroponics system in the production of quality potato (Solanum tuberosum 1.) seed in developing countries. African Journal of Biotechnology, 11(17), 3993-3999. https://doi.org/10.5897/ ajb10.1138 
Dianawati, M., Ilyas, S., Wattimena, G. A., \& Susila, A. D. (2013). Minituber production of potato aeroponically by determining optimum rate of nitrogen foliar fertilizer. Jurnal Hortikultura, 23(1), 47-55. https://doi.org/ 10.21082/jhort.v23n1.2013.p47-55

Fadhil, M., Argo, B. D., \& Hendrawan, Y. (2015). Rancang bangun prototype alat penyiram otomatis dengan sistem timer RTC DS1307 berbasis mikrokontroler Atmega16 pada tanaman aeroponik. Jurnal Keteknikan Pertanian Tropis dan Biosistem, 3(1), 37-43. Retrieved from https://jkptb.ub.ac.id/index. $\mathrm{php} / \mathrm{jkptb} /$ article/view/255

Faramarzi, A., Hassanpanah, D., \& Satarzadeh, R. (2012). The study of mini-tuber production potential of two micro-tubers potato cultivars in different planting beds under greenhouse condition. International Journal of Agronomy and Plant Production, 3(11), 501-507. Retrieved from https://www.cabdirect.org/cab direct/abstract/20123393237

Feng, J., Yuan, L., \& Bao-zhong, H. (2012). Overview of plant shooting branch. Journal of Northeast Agricultural University (English Edition), 19(2), 74-85. https://doi.org/10.1016 /s1006-8104(13)60042-2

Hidayat, I. M. (2016). Produksi Benih Sumber (G0) Beberapa varietas kentang dari umbi mikro. Jurnal Hortikultura, 21(3), 197-205. https://doi.org/10.21082/jhort.v21n3.2011.p1 97-205

Karjadi, A. K. (2014). Pengaruh penyemprotan $\mathrm{GA}_{3}$ dan asal tanaman induk dalam memperpanjang masa juvenile tanaman kentang. Agrin, 18(2), 97-106. https://doi.org/ 10.20884/1.agrin.2014.18.2.216

Karjadi, A. K., \& Waluyo, N. (2017). Pengaruh penambahan BAP dan $\mathrm{GA}_{3}$ terhadap pertumbuhan tunas in vitro tanaman kentang (Solanum tuberosum L). Prosiding Seminar Nasional Pengembangan Teknologi Pertanian, September, 9-14. Retrieved from https://jurnal.polinela.ac.id/index.php/PROSI DING/article/view/698

Kianmehr, B., Parsa, M., Otroshy, M., Nassiri Mohallati, M., \& Moradi, K. (2012). Effect of plant growth regulators during in vitro phase of potato microtuber production. Journal of Agricultural Technology, 8(5), 1745-1759. Retrieved from http://ijat-aatsea.com/pdf/v8 n5_12_July/18_IJAT_2012_8(5)_Behzad_Ki anmehr-Plant_Science-ok_T.pdf

Kumlay, A. M. (2014). Combination of the auxins NAA, IBA, and IAA with GA3 improves the commercial seed-tuber production of potato (Solanum tuberosum L.) under in vitro conditions. BioMed Research International, 2014, 1-7. https://doi.org/10.1155/2014/439 259

Mbiyu, M. W., Muthoni, J., Kabira, J., Elmar, G., Muchira, C., Pwaipwai, P., Ngaruiya, J., Otieno, S., \& Onditi, J. (2012). Use of aeroponics technique for potato (Solanum tuberosum) minitubers production in Kenya. Journal of Horticulture and Forestry, 4(11), 172-177. https://doi.org/10.5897/JHF12.012

Momena, K., Adeeba, R., Mehraj, H., Jamal Uddin, A. F. M., Islam, S., \& Rahman, L. (2014). In vitro microtuberization of potato (Solanum tuberosum L.) cultivar through sucrose and growth regulator. Journal of Bioscience and Agriculture Research, 2(2), 76-82. https://doi.org/10.18801/jbar.020214. 22

Munarti, \& Kurniasih, S. (2014). Pengaruh konsentrasi IAA dan BAP terhadap pertumbuhan stek mikro kentang secara in vitro. Jurnal Pendidikan Biologi, 1(1), 17-25. Retrieved from https://repository.unpak.ac.id/ tukangna/repo/file/files-20180603032027.pdf

Muthoni, J., Shimelis, H., \& Melis, R. (2013). Alleviating potato seed tuber shortage in developing countries: Potential of true potato seeds. Australian Journal of Crop Science, 7(12), 1946-1954. Retrieved from https:// www.researchgate.net/publication/326352704 _Alleviating_potato_seed_tuber_shortage_in_ developing_countries_Potential_of_true_potat o_seeds

Neforawati, I., Herman, N. S., \& Mohd, O. (2019). Precision agriculture classification using convolutional neural networks for paddy growth level. Journal of Physics: Conference Series, 1193(1). https://doi.org/10.1088/17426596/1193/1/012026 
Nuraini, A., Rochayat, Y., \& Widayat, D. (2016). Rekayasa source - sink dengan pemberian zat pengatur tumbuh untuk meningkatkan produksi benih kentang di dataran medium desa Margawati kabupaten Garut. Kultivasi, 15(1), 14-19. https://doi.org/ 10.24198/kultivasi.v15i1.12002

Otazu, V. (2010). Manual on quality seed potato production using aeroponics. Lima, Peru: International Potato Center. Retrieved from https://cipotato.org/wp-content/uploads/2014/ 08/005447.pdf

Pratama, A. R., Sugiyono, S., Prayoga, L., \& Husni, A. (2014). Upaya memacu pertumbuhan tunas mikro kentang kultivar granola dengan jenis dan konsentrasi sitokinin berbeda. Scripta Biologica, 1(3), 209. https:// doi.org/10.20884/1.sb.2014.1.3.553

Roumeliotis, E., Visser, R. G. F., \& Bachem, C. W. B. (2012). A crosstalk of auxin and GA during tuber development. Plant Signaling and Behavior, 7(10), 1360-1363. https://doi.org/ 10.4161/psb.21515

Rykaczewska, K. (2016). The potato minituber production from microtubers in aeroponic culture. Plant, Soil and Environment, 62(5), 210-214. https://doi.org/10.17221/686/2015PSE

Salem, J., \& Hassanein, A. M. (2017). In vitro propagation, microtuberization, and molecular characterization of three potato cultivars. Biologia Plantarum, 61(3), 427-437. https:// doi.org/10.1007/s10535-017-0715-x

Schimmelpfennig, D. (2016). Farm Profits and Adoption of Precision Agriculture. Economic Research Report, 217, 46. Retrieved from https://www.ers.usda.gov/webdocs/publicatio ns/80326/err-217.pdf?v=0

Shafi, U., Mumtaz, R., García-Nieto, J., Hassan, S. A., Zaidi, S. A. R., \& Iqbal, N. (2019). Precision agriculture techniques and practices: From considerations to applications. Sensors (Switzerland), 19(17), 1-25. https://doi.org/ 10.3390/s19173796

Sonnewald, S., \& Sonnewald, U. (2014). Regulation of potato tuber sprouting. Planta, 239(1), 27-38. https://doi.org/10.1007/s004 25-013-1968-z
Statistics Indonesia. (2020). SIMSPH online, survey pertanian hortikultura yang mencakup data produksi buah-buahan dan sayuran tahunan per kecamatan di seluruh wilayah Indonesia. Badan Pusat Statistik. Retrieved from https://www.bps. go.id/indicator/55/62/1/produksi-tanaman-bua h-buahan.html

Sugiyono, Prayoga, L., Proklamasiningsih, E., Faozi, K., \& Prasetyo, R. (2021). The improvement of mini tuber production of granola potato cultivar in aeroponics system. Biosaintifika: Journal of Biology \& Biology Education, 13(1), 77-83. Retrieved from https://journal.unnes.ac.id/nju/index.php/biosa intifika/article/view/27714

Sumarni, E., Sumartono, G. H., \& Saptomo, S. K. (2013). Aplikasi zone cooling pada sistem aeroponik kentang di dataran medium tropika basah. Jurnal Keteknikan Pertanian, 1(1), 99106. Retrieved from https://journal.ipb.ac.id/ index.php/jtep/article/view/9641

Tierno, R., Carrasco, A., Ritter, E., \& de Galarreta, J. I. R. (2014). Differential growth response and minituber production of three potato cultivars under aeroponics and greenhouse bed culture. American Journal of Potato Research, 91(4), 346-353. https://doi. org/10.1007/s12230-013-9354-8

Tiwari, J. K., Devi, S., Buckseth, T., Ali, N., Singh, R. K., Zinta, R., Dua, V. K., \& Chakrabarti, S. K. (2020). Precision phenotyping of contrasting potato (Solanum tuberosum L.) varieties in a novel aeroponics system for improving nitrogen use efficiency: In search of key traits and genes. Journal of Integrative Agriculture, 19(1), 51-61. https://doi.org/10.1016/S2095-3119(19)62625 $-0$

Wang, C. C., Wang, X. Y., Wang, K. X., Hu, J. J., Tang, M. X., He, W., \& Vander Zaag, P. (2018). Manipulating aeroponically grown potatoes with gibberellins and calcium nitrate. American Journal of Potato Research, 95(4), 351-361. https://doi.org/10.1007/s12230-0189635-3

Wulandari, N. W., Heddy, S., \& Suryanto, A. (2014). Penggunaan bobot umbi bibit pada peningkatan hasil tanaman kentang (Solanum 
tuberosum L.) $\mathrm{G}_{3}$ dan $\mathrm{G}_{4}$ varietas Granola. Jurnal Produksi Tanaman, 2(1), 65-72.
Retrieved from http://protan.studentjournal. ub.ac.id/index.php/protan/article/view/80. 